\title{
Is It Time for Some Unpleasant Monetarist Arithmetic?
}

David Andolfatto

\begin{abstract}
Sargent and Wallace (1981) published "Some Unpleasant Monetarist Arithmetic" 40 years ago. Their central message was that a central bank may not have the power to determine the long-run rate of inflation without fiscal support. In a policy regime where the fiscal authority is non-Ricardian, an attempt on the part of the central bank to lower inflation may end up backfiring. I develop a structural model to illustrate this result through the use of a diagram. In addition, I use the model to explain how low inflation, low interest rates, and high primary budget deficits can coexist. I also use the model to explain why it is easier for a central bank to lower inflation than to raise it. I conclude with some recommendations for state-contingent monetary policy. (JEL E4, E5, E6 )
\end{abstract}

Federal Reserve Bank of St. Louis Review, Third Quarter 2021, 103(3), pp. 315-32.

https://doi.org/10.20955/r.103.315-32

\section{INTRODUCTION}

Forty years ago, Sargent and Wallace (1981) suggested that an attempt on the part of a central bank to tighten monetary policy for the purpose of reducing the long-run rate of inflation could conceivably backfire in the absence of fiscal support. This idea seems contrary to the common belief that an "independent" central bank can determine the long-run rate of inflation. For example, the Federal Open Market Committee's (FOMC's) “Statement on Longer-Run Goals and Monetary Policy Strategy"- the FOMC's Nicene Creed, so to speakstates, among other things, that

"The inflation rate over the longer run is primarily determined by monetary policy, and hence the Committee has the ability to specify a longer-run goal for inflation." 1

According to conventional theory, however, the extent to which the Federal Reserve can fulfil its price-stability mandate without any reference to fiscal policy depends on what Leeper (1991) has labeled a passive fiscal policy regime. In such a regime, the central bank recommends a target and uses interest rate policy to stabilize aggregate demand, thereby stabilizing inflation around that target. The fiscal authority, in turn, accommodates central bank policy by absorbing

I thank, without implicating, Marco Bassetto and Miguel Faria e Castro for their comments on an earlier draft. David Andolfatto is senior vice president and economist at the Federal Reserve Bank of St. Louis.

(c) 2021, Federal Reserve Bank of St. Louis. The views expressed in this article are those of the author(s) and do not necessarily reflect the views of the Federal Reserve System, the Board of Governors, or the regional Federal Reserve Banks. Articles may be reprinted, reproduced, published, distributed, displayed, and transmitted in their entirety if copyright notice, author name(s), and full citation are included. Abstracts, synopses, and other derivative works may be made only with prior written permission of the Federal Reserve Bank of St. Louis. 
the fiscal consequences of monetary policy in a manner consistent with stabilizing the long-run debt-to-GDP (gross domestic product) ratio. This conventional division of responsibilities is what Kirsanova, Leith, and Wren-Lewis (2009) label the consensus assignment.

In the scenario considered by Sargent and Wallace (1981), however, the consensus assignment is reversed. In particular, the fiscal authority is assumed not to accommodate the central bank in the manner just described. Instead, it is the central bank that accommodates the budgetary consequences of fiscal policy by generating the necessary seigniorage revenue. It is in this context that attempting to monetize a smaller fraction of outstanding Treasury securities has the effect of increasing the rate of inflation. A tighter monetary policy ends up increasing the interest expense of debt issuance. And if the fiscal authority is unwilling to curtail the rate of debt issuance, the added interest expense must be monetized-at least if outright default is to be avoided.

Sargent and Wallace (1981) examine monetary-fiscal coordination in the context of a standard monetarist model. There is an assumed demand for central bank liabilities. The fiscal authority issues indexed debt. Monetary policy transforms interest-bearing debt into zerointerest reserves, and inflation is the byproduct of debt monetization. $\underline{2}$ The idea, however, is more general than this. Sims (2011), for example, examines the same question using a "fiscal theory of the price level" and arrives at the same answer for essentially the same reason. Future primary budget deficits and surpluses correspond to increases and decreases in the future supply of outside assets, respectively. The inflationary consequences of an increase in the interest rate depends on whether the resulting interest expense is financed with an increase in the primary surplus or an acceleration of nominal debt issuance. The distinction between central bank and Treasury liabilities made by Sargent and Wallace (1981) is not critical in understanding the logic of unpleasant monetarist arithmetic.

Ascertaining the relative dominance of a monetary authority vis-à-vis the fiscal authority at a point in time, or even with the benefit of hindsight, is not always a straightforward exercise. $\underline{3}$ Such analysis presents an added challenge for monetary policymakers because theory suggests that the qualitative properties of a stabilizing interest rate policy depends critically on the nature of the prevailing fiscal regime; see Davig and Leeper (2007).

It seems fair to say there is considerable uncertainty over the nature of the fiscal policy regime prevailing in the United States today. Deficit and debt levels are elevated relative to their historical norms, and the current administration seems poised to embark on an ambitious public spending program. While bond yields remain low relative to historical norms, longer-dated bond yields are beginning to rise. In the event that inflation rises and then remains intolerably above target, the Federal Reserve is expected to raise its policy rate. In theory, this is the conventional policy response necessary to stabilize inflation under a passive fiscal policy regime. But if the fiscal authority is determined to pursue its deficit policy into the indefinite future, raising the policy rate may only keep a lid on inflation temporarily and possibly only at the expense of a recession. $\underline{4}$ In the longer run, an aggressive interest rate policy may contribute to inflationary pressure - at least until the fiscal regime changes. $\underline{5}$ Needless to say, getting the sign wrong on its next policy rate move is something the FOMC will want to avoid. 
The goal of my article here is twofold. First, I want to develop a structural model to address the issue of monetary-fisal policy coordination at a level suitable for, say, advanced undergraduates. A simple model is desirable because the economic mechanisms are readily understandable and are therefore more likely to be taken seriously in policy discussions, assuming they make sense, of course. Structural models are also useful because "first-pass economic intuition" does not always survive the logic test of general equilibrium. To this end, I study a version of the Sargent and Wallace (1981) overlapping generations model and focus mainly on stationary equilibria. ${ }^{6}$ The non-stationary examples studied by Sargent and Wallace (1981) and Sims (2011) constitute interesting (and important) examples of what I think is a more general point that can be illustrated much more simply. Although one could model monetary policy as open market operations in the way Sargent and Wallace (1981) do, I instead employ the cleaner "fiscalist" approach of Sims (2011). And because I use an overlapping generations model, monetary policy can have real effects without having to appeal to assumptions relating to the stickiness of nominal prices. These real effects are potentially important for understanding how a lack of monetary-fiscal coordination can result in recession and how the threat of such an outcome can be used by the monetary authority to potentially discipline fiscal policy.

Second, I use the model to offer what I think is a compelling (or, at least, provocative) reason for why inflation has remained so low in the United States (and in other jurisdictions) despite historically low interest rates and growing primary deficits. The model can also be used to explain why central banks can be expected to be more successful in lowering the long-run rate of inflation than they would be in attempting to raise it.

The model has three key policy parameters: a nominal interest rate; a real primary budget deficit; and a "money" growth rate, where "money" is interpreted broadly to comprise the total supply of outside securities. I assume that the monetary authority determines the nominal interest rate and that the fiscal authority determines the budget deficit and the pace at which the supply of its nominal securities grows over time. The demand for real money balances is influenced by these policy parameters, as well as other factors. All of these variables are linked via a consolidated government budget constraint.

The first thing I demonstrate is that in the long run - which is to say, in a stationary stateinflation is determined by the money growth rate. This may not sound surprising, but since the supply of money is determined by the fiscal authority, the long-run rate of inflation is ultimately a fiscal phenomenon. ${ }^{-}$It follows that the only way for monetary policy to influence the long-run rate of inflation (as opposed to the price level) is by influencing the money growth rate. This is only possible if the fiscal authority permits the primary budget deficit to absorb some or all of the budgetary consequences of interest rate policy. And if it does, then a highinterest-rate policy leads to higher inflation (and vice versa). While this causal relationship seems consistent with the so-called neo-Fisherian proposition (Williamson, 2016), the economic mechanism is very different. In particular, the result I report holds even if rational expectations is not assumed.

Next, I examine the effect of interest rate policy in Ricardian and non-Ricardian fiscal regimes. The analysis here essentially restates known results, albeit in the context of a very 
tractable analytical setting. I also consider the effect of shocks that impinge directly on the demand for Treasury securities. U.S. Treasury securities are used extensively as collateral in wholesale banking arrangements and as a safe store of value for domestic and foreign agencies. There is evidence suggesting that the demand for U.S. Treasury securities has increased significantly over the past 25 years. The analysis here is novel, I think. The model suggests that an increase in the level demand for (real) Treasury balances contributes to persistently high primary budget deficits (in the Ricardian case) and persistently low inflation (in the non-Ricardian case).

Finally, I use the model to study what happens when monetary and fiscal authorities have different preferences regarding inflation. The exercise here is in the spirit of the conflict scenarios studied by Bianchi and Melosi (2019). I consider two thought experiments. In the first experiment, the central bank attempts to keep the rate of inflation lower than the longrun rate implied by the stance of fiscal policy. This is a Volcker scenario. In the second experiment, the central bank attempts to keep the rate of inflation higher that the long-run rate implied by the stance of fiscal policy. This is a Yellen/Powell scenario. The analysis provides a simple reason for why Volcker was successful in bringing inflation down, while Yellen/Powell were not successful in moving inflation higher.

\section{A SIMPLE OVERLAPPING GENERATIONS MODEL}

\subsection{Preferences and Technology}

Time is discrete and denoted $t=0,1, \ldots, \infty$. The population is constant and consists of two-period-lived individuals. There is an initial old generation that lives for one period only. An individual born at date $t$ only values consumption at date $t+1$. In fact, preferences are linear, so $U_{t}=c_{t+1}$ for all $t \geq 0$. Each young person is endowed with $y$ units of output and a storage technology. The storage technology converts $k_{t}$ units of output at date $t$ into $x f\left(k_{t}\right)$ units of output at date $t+1$. The parameter $x$ can be interpreted as the expected productivity of investment. Assume that $f$ is increasing and strictly concave and that $x f^{\prime}(y)<1$. This latter condition implies that a competitive equilibrium without an outside asset, or an intergenerational transfer scheme, is dynamically inefficient.

\subsection{Monetary and Fiscal Policy}

The fiscal authority determines the path of the primary budget surplus $T_{t}-G_{t}$, where $T_{t}$ denotes tax revenue (net of transfers) and $G_{t}$ denotes government purchases of goods and services. In what follows, I set $G_{t}=0$ for all $t$ so that $T_{t}$ denotes the primary surplus and $-T_{t}$ denotes the primary budget deficit.

The fiscal authority issues a single nominal interest-bearing security. Let $D_{t}$ denote the stock of government securities held by the public at date $t$, scheduled to yield interest $i_{t}$ at date $t+1$. Let $R_{t} \equiv\left(1+i_{t}\right)$ The government's flow budget constraint is given by

$$
T_{t}=R_{t-1} D_{t-1}-D_{t}
$$

for all $t \geq 1$ with $D_{0}>0$ endowed to the initial old. 
Let $\mu_{t}$ denote the (gross) rate of growth of the stock of nominal government securities; that is, $\mu_{t}=D_{t} / D_{t-1}$. Let $p_{t}$ denote the price level, and define $\tau_{t} \equiv T_{t} / p_{t}$ and $d_{t} \equiv D_{t} / p_{t}$. Then rewrite (1) as follows:

$$
-\tau_{t}=\left[1-R_{t-1} / \mu_{t}\right] d_{t}
$$

The left-hand side of (2) is the real primary deficit. The right-hand side is the product of two terms, which can be interpreted as a tax rate $\left[1-R_{t-1} / \mu_{t}\right]$ applied against the tax base $d_{t}$, the real value of the outstanding stock of Treasury securities.

There is the question of how to specify policy; see Bassetto and Sargent (2020). In what follows, I simply assume that the fiscal authority determines the paths $\left\{\tau_{t}, \mu_{t}\right\}$ in a manner consistent with (2) under one of two policy regimes, Ricardian or non-Ricardian. In the Ricardian regime, fiscal policy sets a path for bond seigniorage $\left\{\mu_{t}\right\}$ and lets the primary surplus $\left\{\tau_{t}\right\}$ adjust passively to satisfy the government budget constraint (2). In the non-Ricardian regime, fiscal policy determines $\left\{\tau_{t}\right\}$ and lets $\left\{\mu_{t}\right\}$ adjust passively to satisfy (2). The monetary authority in either fiscal regime is assumed to determine the path of $\left\{R_{t}\right\}$.

In the interest of demonstrating the central results in the most straightforward way possible, I assume a set of policies in the form of pegs; that is, $\left\{\tau_{t}, \mu_{t}, R_{t}\right\}=\{\tau, \mu, R\}$ for all $t$. Then, because I restrict attention to stationary equilibria, $d_{t}=d$ for all $t$ so that the government budget constraint (2) can be written as

$$
-\tau=[1-R / \mu] d,
$$

where $d$ is determined endogenously in a competitive equilibrium.

\subsection{Individual Decisionmaking}

A young person at any date $t$ has an exogenous endowment $y$. Since the young only care about consumption when they become old, $y$ also denotes their desired saving. $\stackrel{8}{\text { Consequently, }}$ the young only face a portfolio decision: $y=d_{t}+k_{t}$. Any given portfolio decision $\left(d_{t}, k_{t}\right)$ generates a future payoff equal to

$$
c_{t+1}=x f\left(k_{t}\right)+\left(R / \Pi_{t+1}\right) d_{t}-\tau_{t+1},
$$

where $\Pi_{t+1}=p_{t+1} / p_{t}$ and $\tau_{t+1}$ denotes a real, lump-sum tax (or transfer, if negative). The optimal portfolio choice equates the expected marginal return between capital investment and Treasury securities:

$$
x f^{\prime}\left(k_{t}\right)=\left(R / \Pi_{t+1}\right) .
$$

With investment demand characterized by (5), the real demand for Treasury securities is given by $d_{t}=y-k_{t}$. It follows immediately from (5) that the demand for real Treasury balances $d\left(R / \Pi_{t+1}, x\right)$ is

(i) increasing in the real interest rate $R / \Pi_{t+1}$ and

(ii) decreasing in the expected productivity of capital investment $x$. 
A young person in this model could also be viewed as a bank operating on behalf of a coalition of depositors. Under this interpretation, the bank finances the acquisition of assets $\left(d_{t}, k_{t}\right)$ through the issuance of bank deposit liabilities. The young sell their endowment $y$ to the bank in exchange for bank money (deposits in their bank accounts). It follows that the asset side of the bank's balance sheet respects $y=d_{t}+k_{t}$. This bank money is carried forward by the young where it yields, in real terms and on an after-tax basis, $c_{t+1}$.

Casting the portfolio choice problem from the perspective of a bank is useful because it motivates the introduction of a set of balance sheet restrictions. In reality, regulations govern both bank assets (e.g., liquidity coverage ratio) and liabilities (e.g., capital requirements). As my purpose here is to generate the potential for a regulatory demand for safe assets, I introduce an asset-side restriction that resembles a reserve requirement:

$$
d_{t} \geq \sigma\left(d_{t}+k_{t}\right)
$$

Here, we can think of $d_{t}$ as corresponding to high-quality liquid assets such as reserves and Treasury securities and $k_{t}$ as loans to private sector entities. Condition (6) requires that the bank hold at least a fraction of its assets in the form of high-quality liquid assets, where $\sigma \geq 0$ is a regulatory policy parameter. In this simple model, $d_{t}+k_{t}=y$ with $y$ exogenous, so that the liquidity constraint (6) boils down to $d_{t} \geq \sigma y$. This constraint will either bind or not. If it is slack, then the demand for real Treasury balances is determined by (5). If the constraint binds, then we simply have $d_{t}=\sigma y$ and $x f^{\prime}\left(k_{t}\right)>R / \Pi_{t+1}$.

\subsection{Equilibrium}

Market clearing at date $t$ requires $D_{t}=p_{t} d_{t}$. That is, the old generation ultimately spends their accumulated Treasury balances on output supplied to them by the young at price-level $p_{t}$. Since this condition must hold for all $t$, it holds for $t+1$ as well; that is, $D_{t+1}=p_{t+1} d_{t+1}$. It follows that $\left(D_{t+1} / D_{t}\right)=\left(p_{t+1} / p_{t}\right)\left(d_{t+1} / d_{t}\right)$, or

$$
\mu_{t+1}=\Pi_{t+1}\left(d_{t+1} / d_{t}\right) .
$$

Combine (7) with (5) using $k_{t}=y-d_{t}$ to form the expression

$$
d_{t+1}=\left(\mu_{t+1} / R\right) x f^{\prime}\left(y-d_{t}\right) d_{t} .
$$

Next, consider the government budget constraint (2) for an interest rate peg $R_{t}=R$; that is,

$$
-\tau_{t}=\left[1-R / \mu_{t}\right] d_{t}
$$

An equilibrium in this economy will consist of an initial price-level $p_{0}=D_{0} / d_{0}$ and a set of sequences $\left\{d_{t}, \mu_{t}, \tau_{t}: t \geq 0\right\}$ satisfying (8), (9), and (6) with either $\left\{\mu_{t}\right\}$ or $\left\{\tau_{t}\right\}$ determined exogenously by policy depending on whether the fiscal regime is Ricardian or non-Ricardian, respectively.

In a stationary equilibrium, $\left\{d_{t}, \mu_{t}, \tau_{t}\right\}=\{d, \mu, \tau\}$. Condition (7) implies that the long-run rate of inflation is equal to the rate of growth in the supply of nominal Treasury securities; 
that is, $\Pi=\mu$. This latter object is, of course, controlled by the fiscal authority—not the monetary authority. We immediately have the following important result.

Proposition 1. The long-run rate of inflation is determined by fiscal policy.

The proposition above does not assert that a central bank cannot under any circumstances ever influence the long-run rate of inflation. The proposition suggests that if a central bank is permitted to determine the long-run rate of inflation, it must have the blessing of (and appropriate economic support from) the fiscal authority. $\underline{\text { ? }}$

Given an inflation rate $\mu$, the value of real Treasury balances $(d)$ in a stationary equilibrium is characterized as follows:

$$
\begin{aligned}
& 1=(\mu / R) x f^{\prime}(y-d) \text { if } d>\sigma y \\
& d=\sigma y \text { with } f^{\prime}(y-d)>R / \mu .
\end{aligned}
$$

Condition (10) is derived from (8) evaluated at a steady state, which assumes that the liquidity restriction (6) is slack. Condition (11) considers the case in which the liquidity restriction is binding. If it binds, the marginal product of capital exceeds the real rate of return on Treasury securities. In a stationary equilibrium then, the real value of the stock of Treasury securities depends on a list of parameters: $R / \mu, x, \sigma$. Let $d(R / \mu, x, \sigma)$ denote real Treasury balances under parameter configuration $(R / \mu, x, \sigma)$.

Finally, we have the government budget constraint (9), which, in a stationary state, can be expressed as

$$
-\tau=[1-R / \mu] d(R / \mu, x, \sigma) .
$$

As well, in a stationary state, the price level obeys $p_{t}=D_{t} / d$.

As I am primarily interested in addressing the question of "long run" control of inflation, most of my analysis can focus on stationary equilibria characterized by the equations above. There are, of course, the usual questions pertaining to the existence, uniqueness, and stability of the equilibrium. In what follows, I assume the existence and stability of the equilibrium being studied. I discuss the validity of these assumptions in the appendix, which is on dynamics.

\section{STATIONARY EQUILIBRIA}

The primary deficit $-\tau$ can be interpreted as bond seigniorage. Condition (12) tells us that bond seigniorage is the product of a tax rate $[1-R / \mu]$ applied against a tax base $d(R / \mu, x, \sigma)$. Define the bond-seigniorage function $S(R / \mu, x, \sigma)$ as the right-hand side of $(12)$. Because $[1-R / \mu]$ is increasing in $\mu$ and because $d(R / \mu, x, \sigma)$ is typically decreasing in $\mu$, the function $S$ typically displays the classic "Laffer curve" property. That is, seigniorage revenue is increasing in the rate of inflation at low rates of inflation and decreasing in the rate of inflation at sufficiently high rates of inflation (Figure 1). 


\section{Figure 1}

\section{The Laffer Curve}

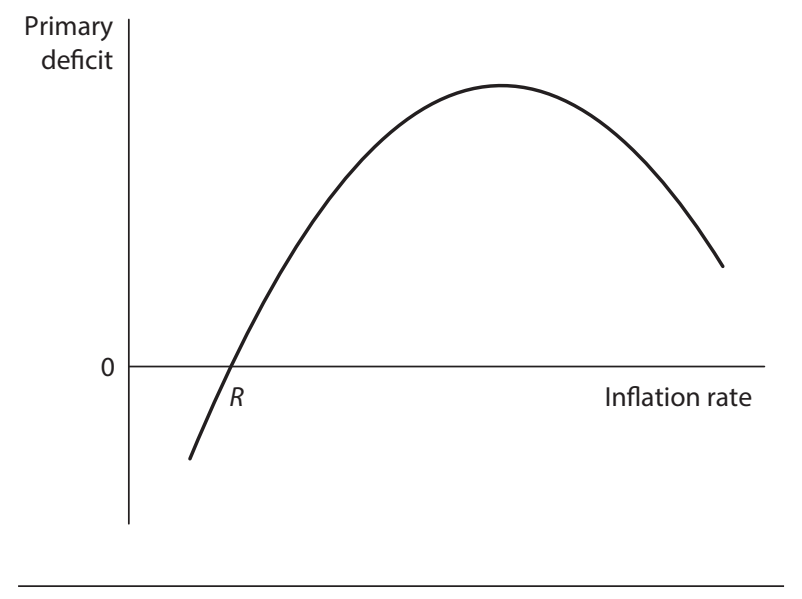

If the liquidity restriction (6) is binding, then $S=[1-R / \mu] \sigma y$ so that $S$ is increasing in $\mu$ with $S \nearrow \sigma y$ as $\mu \rightarrow \infty$ (i.e., there is no backward bending part of the Laffer curve in Figure 1).

Note that bond seigniorage is positive only if $R<\mu$. This is the case I focus on below. If $R>\mu$, then a primary surplus is needed to finance the real interest expense of rolling over the debt.

\subsection{Ricardian Regime}

In a Ricardian regime, the fiscal authority chooses $\mu$ and lets $\tau$ adjust passively to satisfy the government budget constraint. Assuming some weak regularity conditions on $f$, there exist two stationary equilibria in a Ricardian regime (when $R<\mu$ ): One is degenerate $(d=0)$, and the other satisfies condition (10). As it turns out, the non-degenerate equilibrium is unstable. Absent any liquidity restriction, the economy is prone to hyperinflation; see Figure A1 in the appendix.

A solution here is to impose the legal restriction (6). In this case, the stable equilibrium corresponds to the case in which $d=\sigma y$. Consequently, the relevant seigniorage function is given by $S=[1-R / \mu] \sigma y$ so that the stationary equilibrium must satisfy

$$
-\tau=[1-R / \mu] \sigma y
$$

In this regime, fiscal policy is determining $\mu$, the long-run rate of inflation. I want to consider two experiments. First, what happens if the monetary authority raises its policy rate? Second, for a given interest rate policy, what happens if there is an increase in the regulatory demand for Treasury securities? Because I am examining stationary states, both changes should be interpreted to be permanent in nature. 
Figure 2

Increase in the Interest Rate

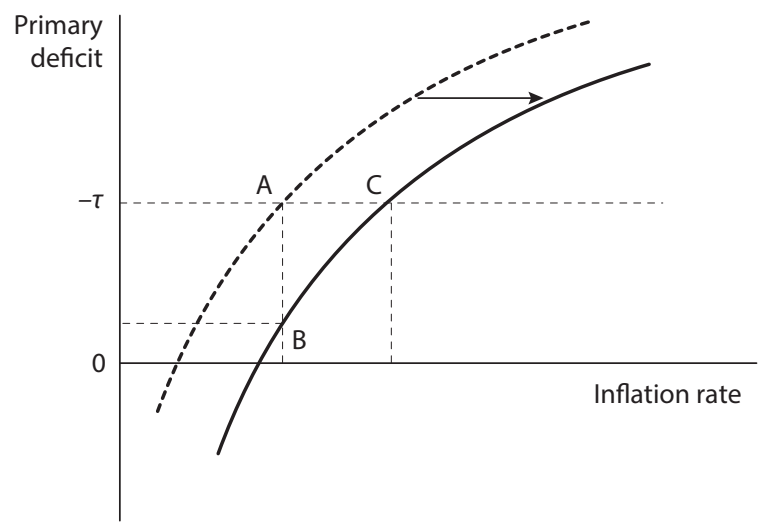

\section{Figure 3}

\section{Increase in the Demand for U.S. Treasuries}

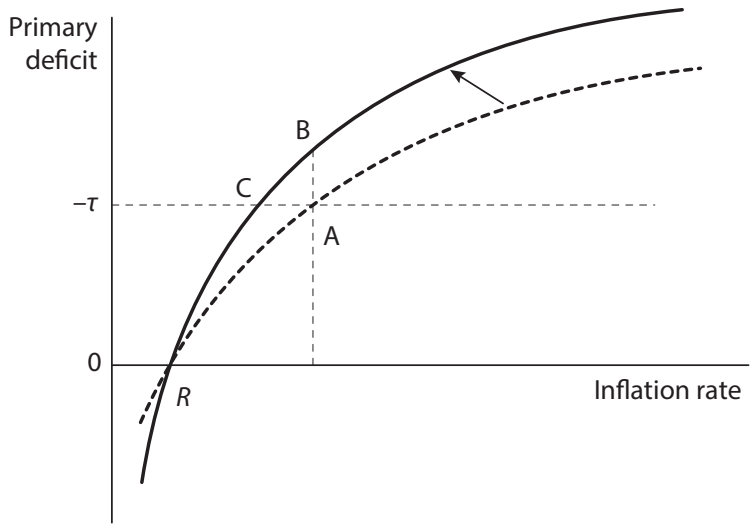

Proposition 2. In a Ricardian fiscal regime, an increase in the interest rate $R$ leads to a decline in the primary deficit, $-\tau$.

Proposition 2 states that, under a Ricardian regime in which the fiscal authority targets the long-run inflation rate, an increase in the policy rate simply serves to increase the real interest rate on government debt. Since the real value of the debt is fixed in this example, the interest expense of the debt must rise, necessitating either an increase in taxes or a decrease in government spending (austerity). An increase in $R$ to $R^{\prime}$ is depicted in Figure 2 by a rightward shift in the Laffer curve. From the initial position A, the primary deficit moves to point $B$.

Next, consider an increase in the demand for Treasury securities.

Proposition 3. In a Ricardian fiscal regime, an increase in the regulatory demand for government securities $\sigma$ leads to an increase in the primary deficit, $-\tau$.

An increase in the demand for Treasury securities is depicted in Figure 3 as a leftward shift of the Laffer curve. If the inflation rate remains pegged at its target, the result is an increase in the primary deficit (point A moves to point B).

Proposition 3 is interesting because it suggests that the growing primary budget deficits in recent years may to some extent be a byproduct of an elevated demand for U.S. Treasury securities working against a fiscal authority that, implicitly, at least, wishes to support a given inflation target. Any failure to accommodate any increase in the demand for government debt through the primary deficit must manifest itself in other ways. One way would be to let inflation absorb the pressure. I explore this possibility in the next section.

\subsection{Non-Ricardian Regime}

In a non-Ricardian regime, the fiscal authority chooses $\tau$ and lets $\mu$ adjust passively to satisfy the government budget constraint. Here, I ignore the liquidity restriction (6) but 
examine it in the appendix. This is also the case considered by Bassetto and Cui (2018). As in their analysis, under weak conditions, for a primary deficit that is not too large, there exists two non-degenerate stationary equilibria $\mu^{L},<\mu^{H}$ satisfying (12); that is,

$$
\begin{gathered}
-\tau=\left[1-R / \mu^{L}\right] d\left(R / \mu^{L}, x, \sigma\right) \\
-\tau=\left[1-R / \mu^{H}\right] d\left(R / \mu^{H}, x, \sigma\right) .
\end{gathered}
$$

As I demonstrate in the appendix (and consistent with Bassetto and Cui, 2018), the equilibrium $\mu^{H}$ is stable, whereas the equilibrium $\mu^{L}$ is not. However, if we impose the liquidity restriction (6) such that $\sigma y>d\left(R / \mu^{H}, x, \sigma\right)$, then equilibrium $\mu^{H}$ is infeasible; see Figure A2 in the appendix. In this case, the only equilibrium is the stationary equilibrium associated with $\mu^{L}$. The comparative statics that follow will therefore focus on the $\mu^{L}$ equilibrium.

In the neighborhood of the $\mu^{L}$ equilibrium, the seigniorage function $S=[1-R / \mu] d(R / \mu, x, \sigma)$ is strictly increasing in $\mu$. But because the liquidity restriction does not bind (it nevertheless plays a role in equilibrium selection), the demand for securities $d(R / \mu, x, \sigma)$ is not influenced by small changes in $\sigma$. Treasury demand is, however, influenced by the "news shock" $x$. As explained earlier (see the discussion surrounding condition (5)), the demand for debt is increasing in bad news (a decline in $x$ ). That is, a downward revision in the forecast of the return to capital induces a "flight to quality."

I want to reconsider the two experiments above, replacing an increase in $\sigma$ (regulatory demand) with a decrease in $x$ (flight to quality) in the context of the non-Ricardian fiscal policy regime in which $-\tau$ is held fixed.

Proposition 4. In a non-Ricardian fiscal regime, an increase in the interest rate $R$ leads to an increase in the rate of inflation, $\mu$.

The experiment in Proposition 3 is depicted by the movement from point $\mathrm{A}$ to point $\mathrm{C}$ in Figure 2. While an increase in the interest rate increases the primary surplus in a Ricardian regime, here it increases the rate of inflation instead (Proposition 4). This is a simple application of "unpleasant monetarist arithmetic" and, indeed, I do not think there is a simpler way to exposit the result. The intuition is straightforward: An increase in the interest rate increases the interest expense of the debt and, if the primary deficit remains unchanged, something else has to give. In reality, the equilibrating forces may manifest themselves along several dimensions. But in this model, the pressure is released via a higher rate of money growth that is necessary to finance the now higher interest expense.

Proposition 5. In a non-Ricardian fiscal regime, an increase in the safe demand for government securities (decrease in $x$ ) leads to a decrease in the rate of inflation, $\mu$.

In the Ricardian regime, an increase in the demand for government debt manifests itself as an increase in the primary deficit (Proposition 3). In the non-Ricardian regime, where the primary deficit is fixed, the equilibrating force manifests itself as a lower inflation rate (Proposition 5). The increase in money demand implies an increase in the purchasing power 
of money which, in turn, implies that the Treasury can slow the pace of money creation and still maintain its level of desired purchasing power. This is depicted in Figure 3 as movement from point $\mathrm{A}$ to point $\mathrm{C}$.

\subsection{Understanding Lowflation}

Through the lens of standard New Keynesian models, the low inflation era since the 2008-09 Financial Crisis presents a bit of a puzzle. This is not what a conventional Phillips curve theory of inflation predicts should happen over the course of an economic recovery. There are, of course, valiant attempts to "fix" the theory; see, for example, Lindé and Trabandt (2019). But perhaps there is a simpler explanation.

There is considerable anecdotal evidence suggesting that the demand for U.S. Treasuries and other safe assets has grown over time. The demand for U.S. Treasuries as collateral for credit derivative markets and repo markets has expanded steadily since the 1980s. The foreign demand for U.S. Treasuries as a safe store of value accelerated following a series of financial crises in the 1990s. The 2008-09 Financial Crisis both reduced the supply of private-label safe assets and increased the demand for U.S. Treasuries. The European sovereign debt crisis did the same thing. The growth in demand for safe assets was further fueled by regulatory changes stemming from the Dodd-Frank Act and Basel III. More recently, a number of stablecoin enterprises are using U.S. Treasuries as collateral for their fixed-exchange rate money funds.

I think we can draw on the propositions above to interpret the following joint developments over the past decade: (i) inflation has remained low, (ii) interest rates have remained low, and (iii) the primary deficit has increased. To some people, this joint behavior may seem puzzling. Shouldn't low interest rates stimulate inflationary pressure? Shouldn't an elevated debt level and large primary deficits be associated with high interest rates?

The model above offers the following explanation. The key exogenous shock has to do with the forces that have increased the global demand for U.S. Treasury securities. In the context of the analysis above, this is modeled as an increase in regulatory demand $(\sigma)$ and/or a bearish sentiment $(x)$. In an open economy version of this model, one could explicitly consider an increase in foreign demand for U.S. Treasury securities. Given these parameter shifts, the model predicts some combination of persistently lower inflation and higher primary deficits, depending on how close fiscal policy is to the Ricardian or non-Ricardian fiscal regimes described above.

At the same time, given the Fed's policy of lowering its policy rate against below-target inflation, we can use Proposition 4 to understand how Fed policy might further have contributed to keeping inflation persistently below target. This is essentially unpleasant monetarist arithmetic in reverse. To the extent that policy is non-Ricardian (as manifested by resistance to increasing the real primary deficit any further), lowering the interest expense on Treasury debt means a slower pace of Treasury issuance and, hence, even lower inflation. To put things another way, monetary policy may have gotten the sign wrong on the way down. Might it similarly get the sign wrong on the way up? 


\section{Figure 4}

\section{U.S. Budget Deficits and PCE Inflation, Fiscal Years 1954-2020}

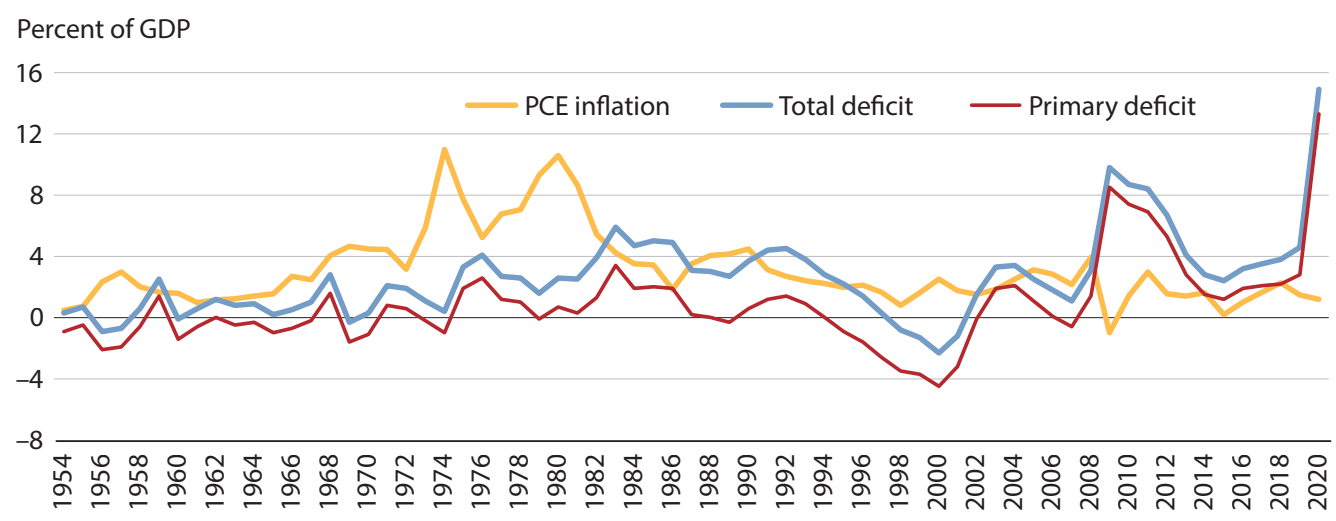

SOURCE: Bureau of Economic Analysis and the Office of Management and Budget.

\section{ASYMMETRY IN THE GAME OF CHICKEN}

\section{1 Volcker Disinflation}

One reason why the Federal Reserve is assumed by many to determine the long-run rate of inflation is because it seems to have demonstrated its willingness and ability to do so under the Volcker regime (1979-87). The standard narrative surrounding that episode is that the fiscal profligacy of the late 1960s and 1970s (war in Vietnam, war on poverty) and its monetary accommodation led to the great "peace time inflation" of the 1970s. Then came Fed Chair Paul Volcker who adopted a tight money policy that eventually led to a lower long-run rate of inflation.

While there are a few problems with this narrative, it no doubt contains an element of truth. In particular, Volcker's policies may very well have encouraged the fiscal restraint that came following the initial 1981 tax cut, through the considerable pain inflicted on the electorate and their representatives in office. $\underline{10}$

In this model, the price level can be influenced by the interest rate through the effect that it has on the demand for real Treasury balances. An increase in the policy rate will, ceteris paribus, increase the relative attractiveness of holding Treasury securities, $d$. And so, for a given stock of nominal Treasury securities $D_{t}$, the market-clearing condition $p_{t} d_{t}=D_{t}$ suggests that on impact, the effect of increasing the policy rate will be downward pressure on the price level. In the model, this is a within-period jump down in the price level. To the extent that such adjustment takes time, it would manifest itself as a transitory decline in the inflation rate.

In this manner, the central bank may be able to keep inflation low, for a period of time at least, by promising an ever-increasing policy rate. $\underline{11}$ To the extent that every policy rate hike induces further portfolio substitution into government securities, capital investment collapses and the economy goes deeper into recession. At the same time, the central bank is increasing 
Figure 5

U.S. Annual Inflation Rate, 2001:01-2020:12

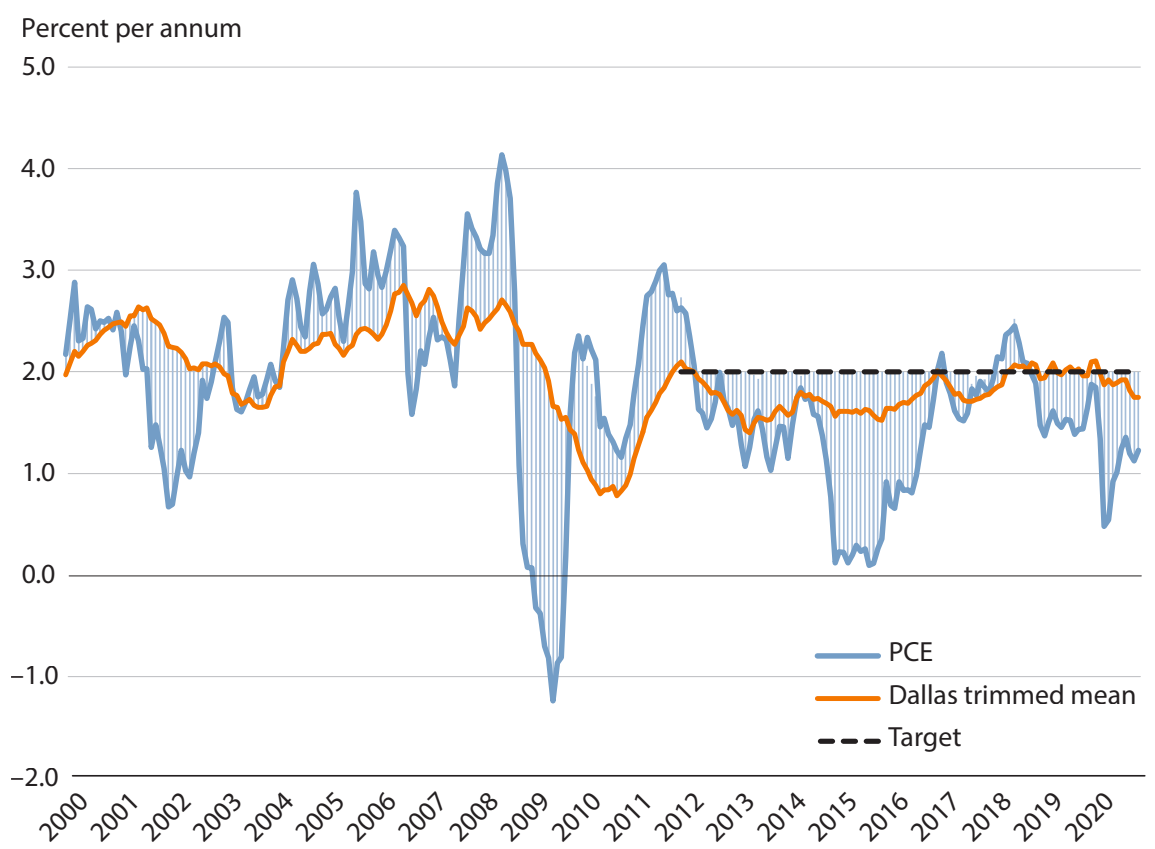

SOURCE: Bureau of Economic Analysis and Federal Reserve Bank of Dallas.

the interest expense of government debt. This is a "double whammy" that may very well induce the fiscal authority to capitulate to the central bank's desire (presumably based on the central bank's Congressional mandate) for lower long-run inflation.

By the way, the standard narrative that high deficits were driving inflation higher in the late 1960s and 1970s seems inconsistent with the fact that the primary deficits in that time frame were not astronomically high, especially taking into account the large supply shocks that hit the U.S. economy during that period (Figure 4).

While the primary deficit did shoot up in the early 1980s, this was in large part owing to the recession caused by Volcker. While the 1981 Reagan tax cut obviously played a role, the tax increases that came later are less well known (Fox, 2017). Note, in particular, how the primary deficit came down over time. The 1986 tax reform essentially sent the primary deficit to zero. Nevertheless, the total deficit remained high throughout the 1980s. The main reason for this is because Volcker's policies kept interest rates high. Ironically, it was largely the Fed causing the high deficits of the period. The fiscal authority was well on its way to balanced budgets, net of interest expenses.

\subsection{Yellen/Powell Lowflation}

Since Volcker showed us how a sufficiently determined central bank can lower the longrun rate of inflation, there is a presumption that the same should be true for a central bank 
determined to raise the long-run rate of inflation. Ironically, the Fed has missed its official inflation target from below almost every year since it officially announced the 2 percent target in 2012 (Figure 5)—despite the Fed's self-described "accommodative" monetary policy stance (near zero interest rate and large-scale securities purchases).

The model developed above suggests that lowering the policy rate leads to an increase in the price level. So, there is a sense in which loosening monetary policy generates transitory inflationary pressure. But there are two clear obstacles keeping even the most determined Fed from generating a persistently higher rate of inflation. First, there is the effective lower bound on interest rates. Second, instead of creating pain for the fiscal authority, the attempt to raise inflation creates fiscal pleasure. That is, instead of recession, the model predicts an economic boom. And instead of increasing the interest expense of the debt, the central bank is lowering it. Needless to say, one would not expect fiscal capitulation in a case like this.

\section{POLICY IMPLICATIONS}

The question for monetary policymakers today is whether the standard prescription of increasing the policy interest rate aggressively against signs of inflation remains appropriate in an environment where the traditional fiscal support for inflation targeting seems to be waning. I want to be clear here: I am not saying this is happening today or that it will happen in the future. I am saying that it might happen and that if it does, it would be good for monetary policymakers to have a contingency plan in place. What should this contingency plan look like?

To take a concrete example, suppose that the tax and spend decisions coming from Congress imply an elevated primary deficit for the foreseeable future. Perhaps there's been a "regime change" in thinking that transcends political parties, so, no matter who controls Congress, the expectation is for elevated primary deficits for as long as we can see. (I am not suggesting this is good or bad, I'm just saying suppose.)

Next, suppose the economy is operating at or near what anyone would call "full employment." And then suppose inflation rises to 3 percent, 4 percent, 5 percent, or higher and stays there with no sign of ever returning to the Fed's official 2 percent long-run inflation target. What should the FOMC do in this hypothetical scenario?

The monetary policy advice coming from a model like Sargent and Wallace (1981) might suggest something like this: For as long as Congress remains in a regime of high primary deficits,

(i) keep the policy rate low, or even lower it, if possible, and

(ii) announce a temporarily higher inflation target (consistent with the new fiscal regime).

Recommendation (i) comes from "Some Unpleasant Monetarist Arithmetic" (Sargent and Wallace (1981). Increasing the interest rate in this fiscal regime will only lead to higher inflation. Lowering the interest rate has the opposite effect. If recommendation (ii) is not adopted, the monetary authority would have to explain (after every meeting) why it is missing its 2 percent inflation target. They might, of course, just say it's "temporary," but this would wear thin after a few years.

This advice is based on the assumption that everyone knows there's been a change in fiscal regime and that it will be persistent. What if no one is really sure if the regime changed, or 
what if they know it changed but not how long it might last? A more prudent policy in this more realistic case is to hedge one's bets. In terms of (i), one might recommend raising the policy rate, but not by as much as would normally be done given the observed inflationary pressure. In terms of (ii), one could probably get away with maintaining the long-run inflation target at 2 percent and legitimately explaining away deviations from target as "transitory." Probably the last thing monetary policy should do under these circumstances is to raise the policy rate aggressively against inflationary pressure (as recommended by the Taylor principle). The Taylor rule is designed to work under a Ricardian fiscal policy. But it may backfire if fiscal policy is non-Ricardian. This was the whole point of Sargent and Wallace (1981).

Tightening monetary policy might have the effect of bringing inflation down temporarily (this is consistent with the Sargent and Wallace model). But in reality, such a policy is likely to come at the cost of economic recession. I can see no economic rationale for creating a recession to bring inflation down temporarily. But there may be a political-economy rationale for the threat of such a policy. That is, a Congress that does not fully trust future Congresses may want to create an independent (but accountable) central bank to pursue a low-inflation mandate and to do whatever it can with interest rate policy to achieve that mandate, even at the cost of recession. As a result, future Congresses may be compelled to behave in a Ricardian manner (with only temporary deficits permitted) so that the goal of anchoring the long-run rate of inflation may be achieved without monetary and fiscal policy coming to blows.

\section{APPENDIX: DYNAMICS}

Consider equations (8) and (9). Because the primary surplus adjusts passively in this case, we can ignore condition (9). Let me begin in the Ricardian regime with $\mu_{t}=\mu$. Condition (8) may therefore be written as

$$
d_{t+1}=(\mu / R) x f^{\prime}\left(y-d_{t}\right) d_{t} \equiv G\left(d_{t}\right) .
$$

The function $G$ satisfies $G(0)=0, G^{\prime}(d)>0$. If $f^{\prime \prime \prime}(k)$ is sufficiently small (e.g., zero), then $G^{\prime \prime}(d)>0$. In this case, we get the mapping displayed in Figure A1. In the main text, I assumed a binding liquidity regulation, as displayed in Figure A1. Point A corresponds to the stable stationary state discussed in the main text. Point B is the unstable stationary state. Any initial condition $d_{0}$ larger than point $\mathrm{B}$ cannot be a perfect foresight equilibrium, since the implied deflation would imply a real demand for debt that would exceed the real gross domestic product. Any initial condition below point B but strictly positive converges to point A. And so, technically, there exists a continuum of dynamic equilibria (the initial price-level is indeterminate). In any case, note that for small changes in $\sigma$, there are no dynamics.

Let us now consider the non-Ricardian regime with $\tau_{t}=\tau<0$. By combining (8) and (9), we can derive

$$
d_{t+1}=x f^{\prime}\left(y-d_{t}\right) d_{t}-\tau \equiv H\left(d_{t}\right)
$$


Figure A1

\section{Ricardian Dynamics}

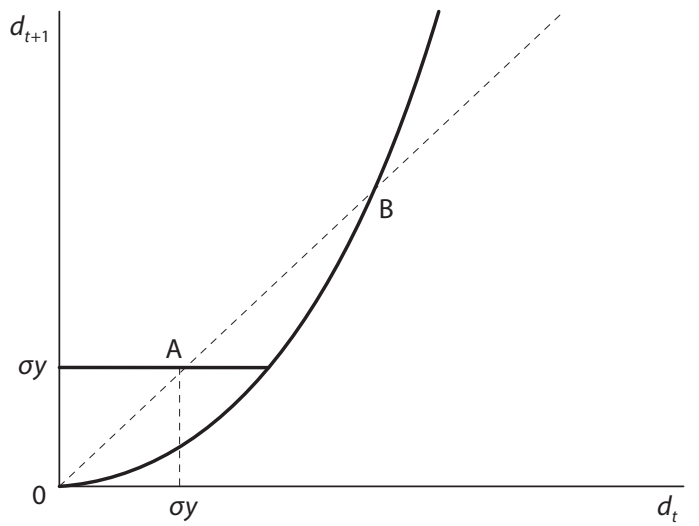

\section{Figure A2}

\section{Non-Ricardian Dynamics}

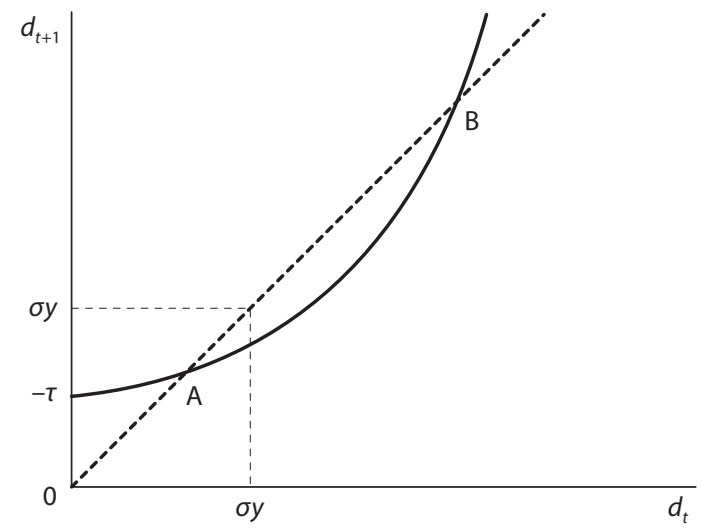

The function $H$ satisfies $H(0)=-\tau>0, H^{\prime}(d)>0$. If $f^{\prime \prime \prime}(k)$ is sufficiently small (e.g., zero), then $H^{\prime \prime}(d)>0$. In this case, we get the mapping displayed in Figure A2. If the primary deficit is not too large, there exist two stationary equilibria, depicted by points $\mathrm{A}$ and $\mathrm{B}$. Once again, the equilibrium at point $A$ is stable, while the equilibrium at point $B$ is unstable.

The analysis in the main text focused on equilibrium B in Figure A2. This was justified by imposing a liquidity restriction sufficiently severe to rule out point $A$ and not point $B$; see Figure A2. Under this parameter configuration, point B is the unique perfect foresight equilibrium (there is no price-level indeterminacy). 


\section{NOTES}

1 Board of Governors of the Federal Reserve System (2021).

$\underline{2}$ See also Aiyagari and Gertler (1985).

$\underline{3}$ Favero and Monacelli (2003) find that U.S. inflation is better accounted for in a statistical model that explicitly incorporates changes in fiscal policy regimes; see also Favero and Monacelli (2005). Davig and Leeper (2006) examine changes in U.S. monetary and fiscal policy regimes through the lens of a structural model; see also Bianchi and llut (2017).

4 See Sims (2011) and Bianchi and Melosi (2019).

5 Loyo (1999) describes how high interest rate policy in Brazil in the late 1970s and early 1980s contributed to higher, not lower, inflation.

6 Bassetto and Cui (2018) also study the properties of a simple overlapping generations model, but their focus is on the fiscal theory of the price level as an equilibrium selection device.

$\underline{z}$ This result is not sensitive to an alternative specification in which the price level is proportional to the supply of central bank liabilities (reserves). In a stationary equilibrium, the reserves-to-debt ratio is constant, so the supply of reserves must grow at the same rate as the supply of nominal debt; see Andolfatto and Spewak (2019).

$\underline{8}$ It would be easy to incorporate a consumption-saving decision as in Basseto and Cui (2018). Doing so would not change the conclusions that follow.

9 In Canada, for example, both the Bank of Canada and the government of Canada jointly sign off every five years on an inflation-control agreement. No such explicit agreement exists in the United States, though the 1951 Treasury-Fed Accord could be interpreted as providing the basis for the consensus assignment described in the introduction.

10 Fed Chair Paul Volcker regularly clashed with Treasury Secretary Donald Regan and other members of the administration (although President Ronald Reagan offered public support for Volcker). Many members of Congress, on both sides of the aisle, supported Volcker's recommendations of fiscal restraint.

11 In a model with money and bonds, the central bank could hold the money supply fixed against an ever-growing supply of bonds. The rising bond-to-money ratio would imply a rising real rate of interest.

\section{REFERENCES}

Aiyagari, S. Rao and Gertler, Mark. "The Backing of Government Bonds and Monetarism." Journal of Monetary Economics, 1985, 6(1), pp. 19-44; https://doi.org/10.1016/0304-3932(85)90004-2.

Andolfatto, David and Spewak, Andrew. "Understanding Lowflation." Federal Reserve Bank of St. Louis Review, First Quarter 2019, 101(1), pp. 1-26; https://doi.org/10.20955/r.101.1-26.

Bassetto, Marco and Cui, Wei. "The Fiscal Theory of the Price Level in a World of Low Interest Rates." Journal of Economic Dynamics and Control, 2018, 89(C), pp. 5-22; https://doi.org/10.1016/j.jedc.2018.01.006.

Bassetto, Marco and Sargent, Thomas J. "Shotgun Wedding: Fiscal and Monetary Policy." Annual Reviews of Economic Policy, 2020, 12(1), pp. 659-90; https://doi.org/10.1146/annurev-economics-091319-050022.

Bianchi, Francesco and llut, Cosmin. "Monetary/Fiscal Policy Mix and Agents' Beliefs." Review of Economic Dynamics, 2017, 107(26), pp. 113-39; https://doi.org/10.1016/j.red.2017.02.011.

Bianchi, Francesco and Melosi, Leonardo. "The Dire Effects of the Lack of Monetary and Fiscal Coordination." Journal of Monetary Economics, June 2019, 14, pp. 1-22; https://doi.org/10.1016/j.jmoneco.2018.09.001.

Board of Governors of the Federal Reserve System. "2020 Statement on Longer-Run Goals and Monetary Policy Strategy." January 14, 2021, update; https://www.federalreserve.gov/monetarypolicy/review-of-monetary-policy-strategy-tools-and-communications-statement-on-longer-run-goals-monetary-policy-strategy.htm.

Davig, Troy and Leeper, Eric M. "Fluctuating Macro Policies and the Fiscal Theory." NBER Macroeconomics Annual, 2006, 21, pp. 247-316; https://doi.org/10.1086/ma.21.25554956. 


\section{Andolfatto}

Davig, Troy and Leeper, Eric M. “Generalizing the Taylor Principle." American Economic Review, 2007, 97(3), pp. 607-35; https://doi.org/10.1257/aer.97.3.607.

Favero, Carlo A. and Monacelli, Tommaso. "Monetary-Fiscal Mix and Inflation Performance: Evidence from the U.S." CEPR Working Paper, 2003, Center for Economic Policy and Research; https://ssrn.com/abstract=416544.

Favero, Carlo A. and Tommaso Monacelli. "Fiscal Policy Rules and Regime (In)Stability: Evidence from the U.S." IGIER Working Paper No. 282, Innocenzo Gasparini Institute for Economic Research, 2005; http://dx.doi.org/10.2139/ssrn.665506.

Fox, Justin. "The Mostly Forgotten Tax Increases of 1982-1993." Bloomberg Opinion, 2017.

Kirsanova, Tatania; Leith, Campbell and Wren-Lewis, Simon. "Monetary and Fiscal Policy Interaction: The Current Consensus Assignment in Light of Recent Developments." Economic Journal, 2009, 119(541), pp. F482-96; https://doi.org/10.1111/j.1468-0297.2009.02317.x.

Leeper, Eric M. “Equilibria Under 'Active' and 'Passive' Monetary and Fiscal Policies." Journal of Monetary Economics, 1991, 27(1), pp. 129-47; https://doi.org/10.1016/0304-3932(91)90007-B.

Lindé, Jesper and Trabandt, Mathias. "Resolving the Missing Deflation and Inflation Puzzles." VOX EU, 2019; https://voxeu.org/article/resolving-missing-deflation-and-inflation-puzzles.

Loyo, Eduardo. "Tight Money Paradox on the Loose: A Fiscalist Hyperinflation." Unpublished manuscript, 1999.

Sargent, Thomas J. and Wallace, Neil. "Some Unpleasant Monetarist Arithmetic." Federal Reserve Bank of Minneapolis Quarterly Review, Fall 1981, pp. 1-15; https://doi.org/10.21034/qr.531.

Sims, Christopher A. "Stepping on a Rake: The Role of Fiscal Policy in the Inflation of the 1970s." European Economic Review, 2011, 55(1): 48-56; https://doi.org/10.1016/j.euroecorev.2010.11.010.

Williamson, Stephen. "Neo-Fisherism: A Radical Idea, or the Most Obvious Solution to the Low-Inflation Problem?" Federal Reserve Bank of St. Louis Regional Economist, July 2016; https://www.stlouisfed.org/publications/regional-economist/july-2016/neo-fisherism-a-radical-idea-or-the-most-obvious-solution-to-the-low-inflation-problem. 